\title{
Cartas D'África e alguma poesia, de Salim Miguel
}

\author{
Érica Antunes Pereira \\ Universidade de São Paulo
}

ascido em Florianópolis e composto inicialmente por Aníbal Nunes Pires, Ody Fraga e Silva, Antônio Paladino, Eglê Malheiros e Salim Miguel, o Grupo Sul legou, para além dos trinta volumes da revista Sul, a comprovação do intercâmbio literário havido entre as duas margens do Atlântico desde o final da década de 1940, época em que Marques Rebelo forneceu a Salim Miguel e seus companheiros o endereço do moçambicano Augusto dos Santos Abranches (MIGUEL, 2005, p. 7-8). Tendo sido contatado, este poeta não tardou para aproximar os brasileiros de outros autores, quer de sua própria terra, Moçambique, quer de outras paragens, como a Angola de António Jacinto (MIGUEL, 2005, p. 61). Assim é que, pouco a pouco, à revista se uniram, dentre outros, nomes como Orlando Mendes, Noémia de Sousa, Glória de Sant'Anna, Francisco José Tenreiro, Viriato da Cruz e Luandino Vieira.

Cartas d'África e alguma poesia, obra organizada por Salim Miguel e publicada em 2005 (Rio de Janeiro, Topbooks), reúne justamente as cartas recebidas pelo casal Eglê Malheiros e Salim Miguel de vários dos autores africanos que colaboraram com a Sul e constitui, como define Juliana Santil (SANTIL, 2006), "un petit livre-musée", pois

elas [as cartas] fizeram um longo trajeto - é bom pôr 'longo' nisto - das então colônias africanas de Portugal até à pequena e pacata Florianópolis. Tem mais, elas circularam por diferentes casas na Ilha e no Rio de Janeiro. Nesse vaivém algumas se extraviaram, mas as remanescentes dão uma idéia do que foi este intercâmbio. (MIGUEL, 2005, p. 7) 
Ao valor literário das cartas, incorpora-se o histórico: muitas delas denunciam a rigidez da censura salazarista, de modo que o contato com o Grupo Sul, cujo lema era "a luta pela liberdade de expressão" (MACÊEDO, 2002, p. 46), foi essencial, permitindo aos autores africanos que, muito embora na longínqua Florianópolis, continuassem publicando seus trabalhos. Ainda nessa senda, várias artimanhas foram empregadas para que os autores africanos tivessem acesso às tantas obras então consideradas perigosas ou subversivas; é o que se vê na carta de Viriato da Cruz datada de 06 de janeiro de 1953:

Para reduzir ao mínimo as possíveis complicações, peço-lhe diligenciar para que os livros não venham como encomenda da livraria em que forem adquiridos, mas sim como encomenda particular, oferta de amigo. Se possível, deverão ser vestidos com capas de outros livros vulgares. E, finalmente, os embrulhos, que deverão ser pouco volumosos, convém sejam feitos de papel forte. (MIGUEL, 2005 , p. 43)

António Jacinto também deixa entrever a preocupação concernente ao envio das encomendas em carta de 09 de outubro de 1955: "Sobre o endereço e cuidados na remessa já sabe" (MIGUEL, 2005, p. 27). Bem mais explícito e nada lacônico, aparece Luandino Vieira - na altura, ainda conhecido como José Graça - que, em 10 de janeiro de 1957, escreve:

O panorama cultural aqui está condicionadíssimo. Temos um bom número de jovens interessados em desenvolver uma literatura de caracter regionalista e alguns mesmo já com obra feita. Mas está guardada no fundo do baú. Não a podem publicar. Não há editores. As edições de autor ficam caríssimas, fora do alcance da gente nova, estudantes uns, pequenos empregados outros.

(...)

Os jornais, controlados, não publicam nada que tenha "regionalismo". De maneira que nos encontramos num beco quase sem saída. Possibilidades econômicas de publicação quase nulas, devido ao elevado preço dos trabalhos gráficos, censura mais que espartilhada, lei de imprensa sem janelas abertas, enfim, se conseguirmos publicar 3 cadernos (mas têm de ser sem caracter de movimento cultural nem de identidade de temas) teremos muita sorte. Temos contudo a vontade para não desistir. (MIGUEL, 2005, p. 30-1) 
Em Moçambique, a situação não era menos complexa, fato que transparece na carta de Manuel Filipe de Moura Coutinho datada de 25 de junho de 1958:

agora, depois das eleições de que V. certamente através da rádio teve melhores notícias do que eu, deixei de colaborar na nossa Imprensa. Não quero continuar a colaborar em jornais de atitudes vendidas ou dirigidas nem naqueles que nunca foram senão de bajulação local ou nacional. (MIGUEL, 2005, p. 109)

Mesmo com tantos empecilhos, a permuta de obras, textos e materiais nunca cessou; muito pelo contrário, surpreende pela quantidade e pela freqüência. Assim é que António Jacinto, por exemplo, em 24 de setembro de 1952, promete enviar para a revista Sul "trabalhos de todos os jovens de Angola, que se preocupam com coisas do espírito" e pede que lhe sejam remetidos "prosa, poesia e desenhos de amigos seus não só para o Farolim como para a revista de Cultura e Arte Mensagem" (MIGUEL, 2005, p. 17-8). De igual maneira, Garibaldino de Andrade, fundador, em 1960, junto com Leonel Cosme, das Edições Imbondeiro na então Sá da Bandeira (LARANJEIRA, 1995, p. 110-2), propõe a Salim Miguel, em 30 de agosto de 1963, que

além dos livros das nossas edições, poderemos mandar quaisquer outras de todos os editores portugueses. O meu amigo mandará livros técnicos, científicos, pedagógicos e até certos livros literários, como Seara Vermelha, do Jorge Amado, que tem muita procura, mas está proibido... (MIGUEL, 2005, p. 50)

Jorge Amado e vários outros escritores e poetas brasileiros já eram conhecidos há muito pelos autores africanos, "vaidadezinha" de que se gaba Augusto dos Santos Abranches em 05 de maio de 1952:

Permita-me uma vaidadezinha: pelo que me diz, daqui devemos conhecer um pouco melhor o Brasil, pois não estamos reduzidos apenas a Machado de Assis. Movimentos e nomes correspondentes a Jorge Amado, Graciliano Ramos, Rachel de Queiroz, José Lins do Rego, etc., são-nos absolutamente familiares, como o são Manuel Bandeira, Carlos Drummmond de Andrade, Jorge de Lima, Raul Bopp, etc., pois que não quero citar essa admirável e minha Cecília Meireles, 
por não consentir que ela seja apenas vossa. Na crítica, admiramos Mário de Andrade (e também o poeta e o contista) tão vivo ainda, Álvaro Lins e Sérgio Milliet. Tantos nomes que poderia citar! (MIGUEL, 2005, p. 58)

Ainda no tocante ao intercâmbio de obras, merece referência o fato de pertencer a Salim Miguel um dos três únicos exemplares que restaram do livro $A$ cidade e a infância de Luandino Vieira, "editado em Luanda, em 1957, apreendido na gráfica e destruído pela ditadura salazarista” (MIGUEL, 2005, p. 9). Em duas das cartas enviadas por Luandino, uma datada de 08 de março e outra de 09 de junho, ambas do ano de 1957, há referências a tal remessa:

Tenho o prazer de lhe enviar em separado o $\mathrm{I}^{\mathrm{o}}$ caderno publicado por nós, $A$ cidade e a infância, contos da $\mathrm{m} /$ autoria. Contos da minha cidade e da minha infância. É o I ${ }^{\mathrm{o}}$ duma série de 2 cadernos c/ o mesmo título.

(...)

PS.: Afinal, amigo S.M., não lhe posso enviar o caderno. Toda a edição foi apreendida pela censura. Logo que haja outro publicado, enviá-lo-ei. Desculpe... já vê em que condições trabalhamos. (MIGUEL, 2005, p. 31-2)

Enviei-lhe também sob registro I exemplar do meu caderno de contos e do livro de poemas Calema. Queira dizer se já os recebeu. (MIGUEL, 2005, p. 32)

A tais peculiaridades que se vão pescando nas cartas, ajunta-se uma observação curiosa: se, ao iniciarem a troca de correspondência, os autores africanos se mostram absolutamente formais, o correr do tempo aproxima os interlocutores de tal modo que um Augusto dos Santos Abranches, por exemplo, em carta datada de 14 de outubro de 1952, não hesita em, carinhosamente, após cobrar uma prometida colaboração, alcunhar Salim Miguel de "diabo duma figa!" (MIGUEL, 2005, p. 71). Cerca de um mês depois, o mesmo Abranches, ainda mais jocoso, escreve: "Afinal, essa prometida colaboração? Casadinhos de fresco, não se lembram de mais nada. Ah, que bom par de açoites!” (MIGUEL, 2005, p. 76). Esse é o clima que, apesar da situação política caótica atravessada sobretudo pelos países de África, parece caracterizar o diálogo entre os autores de lá e de cá; um clima que, de alguma forma, lembra a célebre máxima de Che Guevara: "Hay que endurecer, pero sin perder la ternura jamas”! 
Cartas d'Africa e alguma poesia, portanto, além de preservar a memória de uma época, é também um contributo para a reflexão e para aqueles que, por mera curiosidade ou em caráter científico, buscam (re)conhecer os dois lados do Atlântico.

\section{Referência Bibliográfica}

LARANJEIRA, Pires. Literaturas africanas de expressão portuguesa. Lisboa: Universidade Aberta, 1995.

MACÊDO, Tania. A Revista Sul e o diálogo literário Brasil-Angola. In: Angola e Brasil - estudos comparados. São Paulo: Arte \& Ciência, 2002.

MIGUEL, Salim (org.). Cartas d'África e alguma poesia. Rio de Janeiro: Topbooks, 2005.

SANTIL, Juliana. Un petit livre-musée. 2006. (texto inédito) 